\title{
Parallels Between Near-Death Experience Prophetic Visions and Prophecies from the Bible and Mormon Holy Writ
}

\author{
Craig R. Lundahl, Ph.D.
} Western New Mexico University

\begin{abstract}
In 1982, Kenneth Ring identified a phenomenon where some near-death experiencers were permitted to see a picture of the Earth's future as a "prophetic vision" or PV. In his study of the PV, Ring identified five elements of the PV for the future of the Earth as geophysical changes, meteorological changes, supply and economic breakdowns, nuclear war, and a new era of love and world peace. He also mentioned two other features, the death of many and a time frame for the elements. A comparison of the events of near-death experience prophetic visions of the Earth's future and prophecies from the Bible and the Mormons' Doctrine and Covenants shows nearly complete agreement. These catastrophic events are prophesied to occur on the Earth into the $21^{\text {st }}$ century and to culminate with a new world of peace that is constituted of good people.
\end{abstract}

In 1980, Kenneth Ring coined the term "flashforwards" to refer to the phenomenon in which some near-death experiencers (NDErs) were permitted to see their future life on Earth during their neardeath experience. In George Gallup's 1980-81 nationwide survey of Americans, he found approximately a half million adult Americans, out of eight million of those who had had an NDE, experienced a premonition during their NDE about some event or events that would happen in the future. For example, some of the people in the Gallup

Craig R. Lundahl, Ph.D., is Professor Emeritus of Sociology and Business Administration and Chair Emeritus of the Department of Social Sciences at Western New Mexico University in Silver City, New Mexico. 
study reported "that during near-death encounters or other related experiences, they learned of events that were in the process of happening at some distance or would happen in the future" (Gallup and Proctor, 1982, p. 54).

One type of flashforward investigated and labeled by Ring (1982) was the "prophetic vision" or PV. Prophetic visions differ from the two other types of flashforward-one identified as the personal flashforwards (PF) by Ring (1980) and the other identified as the otherworld personal future revelation (OPFR) by Craig Lundahl (1983)-in that they have a world or global focus and pertain to a picture of the Earth's future, rather than pertaining solely to the personal future of an individual, and they are highly consistent from person to person. Ring (1984) reported that most of the individuals experiencing PVs were shown them during their NDEs, often when they encountered guides or a being of light.

Prophetic vision cases have also been reported by the near-death researcher Margot Grey (1985). Individual prophetic visions have been reported by George Ritchie (1991) and Dannion Brinkley (Brinkley and Perry, 1994). We now know that PVs are usually reported to occur during an NDE, that they involve deep NDEs, and that there are apparently a relatively small number of cases.

The purpose of this article is to examine the amount of congruence between NDE prophetic visions for the Earth's future and prophecy from the Bible and from modern Mormon holy writ in The Doctrine and Covenants.

\section{A Composite Model and Elements of the Prophetic Vision}

Ring (1984) reproduced the following idealized version or composite PV based on information from 16 NDErs:

There is, first, a sense of having total knowledge, but specifically one is aware of seeing the entirety of the earth's evolution and history, from the beginning to the end of time. The future scenario, however, is usually of short duration, seldom extending much beyond the beginning of the twenty-first century. The individual reports that in this decade [1980s] there will be an increasing incidence of earthquakes, volcanic activity and generally massive geophysical changes. There will be resultant disturbances in weather patterns and food supplies. The world economic system will collapse, and the possibility of nuclear war or accident is very great (respondents are not 
agreed on whether a nuclear catastrophe will occur). All of these events are transitional rather than ultimate, however, and they will be followed by a new era in human history, marked by human brotherhood, universal love and world peace. Though many will die, the earth will live. While agreeing that the dates for these events are not fixed, most individuals feel that they are likely to take place during the 1980s. (p. 197)

Four of the five specific elements of the PV scenario for the future of the Earth Ring specified were: (1) geophysical changes of earthquakes, volcanic activity, and landmass changes, (2) meteorological changes, (3) supply and economic breakdowns, and (4) nuclear war. The PVs in Ring's investigation showed the future of the Earth into the beginning of the $21^{\text {st }}$ century and suggested an increasing incidence of upheaval and destruction in the world, of both a social and natural nature. These devastating changes were seen by the neardeath experiencers as a necessary purgation for moving humanity into a new mode of being. They foresaw this transition period being followed, after years of destruction and upheaval, by Ring's fifth element: a new era of human history characterized by universal love and world peace. Ring also mentioned two additional features in his composite model: the death of many people and the time frame for the PV elements.

Ring (1984) characterized the new era of human history with a few quotations from experiencers. Two of those quotations specifically mentioned a Christlike figure or Christ:

...I see a period when those who are good-intentioned and those who have acquired a type of level of spirituality of close bondedness of human relationships, that the being of light, the Christlike figure will be able to swell among us .... (p. 204)

[Christ] will come back and there will also be the Christ-like features in other people. Yes, this is true, He is coming. (p. 204)

\section{The Time Frame for Fulfilling the Prophetic Visions}

Ring found that most of his NDErs felt that the major PV events would occur during the $1980 \mathrm{~s}$. The NDErs did agree that there were no fixed dates for specific events to occur. However, most of them were convinced of the general direction of these events even though none of them seemed to have a complete conception of the details in 
their unfolding. The common view of the subjects was that the PV scenario was inevitable (Ring, 1984, pp. 204-205).

\section{Parallels Between Prophetic Visions and Biblical Prophecy of the Last Days}

The events in NDE prophetic visions appear to parallel the cataclysmic events foretold by ancient prophets and Apostles of the Bible to occur on the Earth prior to the Second Coming of Jesus Christ, who is to reign on the Earth during a peaceful period of a thousand years. Events were foretold by these ancient prophets and Apostles that seem to parallel the events or elements and features found in NDE prophetic visions.

\section{Geophysical Changes}

The Old Testament contains many prophesies concerning the last days. Similar prophecies are also found in the New Testament regarding the coming of Jesus Christ to establish his millennial reign. Ancient prophets predicted commotions of nature would be taking place during the last days. Daniel (12:1) said there would be a time of trouble on the Earth as never known before. Jesus Christ taught his followers that there would be future calamities that would precede his Second Coming when he declared: "There shall be famines, pestilences, and earthquakes, in diverse places" (Matthew 24:7; see also Mark 13:8 and Luke 21:11). The Apostle John foresaw the greatest earthquake as has ever been seen on Earth at the Second Coming (Revelation 16:18). Another force of nature that is a terrible force of destruction is volcanic eruptions. The Apostle John saw "a great mountain burning with fire" that was "cast into the sea" (Revelation $8: 8$ ) in the last days, suggesting the possibility of volcanic activity. Joel (2:30-31) also said there would be "fire and pillars of smoke. The sun shall be turned into darkness, and the moon into blood," which might result from volcanic activity. Landmass changes such as the greatest earthquake ever (Revelation 16:18) at the Second Coming will effect every nation (Haggai 2:6-7) and cause mountains to disappear (Revelation 16:20) and steep places to fall (Ezekiel 38:20), islands to flee away (Revelation 16:20), and the Earth's land masses to join together (Isaiah 62:4). 


\section{Meteorological Changes}

The weather of the future Earth prophesied in the Bible is for famines that are caused by droughts and for thunder and lightening (Revelation 16:18), as well as overflowing waters (Isaiah 28:17), prior to the Second Coming.

\section{Supply and Economic Breakdowns}

Although Biblical scripture did not specifically comment on supply and economic breakdowns as such, or the collapse of the world economic system, it was implied by references to famines, overflowing rain, great hailstones, and fire (Ezekiel 38:22), natural disasters, and wars. In other words, because of the unsettled conditions of the elements and among humankind itself, it is logical to expect economic turmoil.

\section{Nuclear War}

Matthew (24:6-7) foretold of the widespread presence of wars and rumors of wars and of nations fighting other nations in the last days. In the apocalyptic writings of the Apostle John was the foretelling of the most vicious war in history, known as the battle of Armageddon (Revelation 16:16), which could involve nuclear weapons.

\section{Era of Universal Love and World Peace}

The prophet Isaiah described a period of time following the Second Coming that would be a period free of wars and of world peace for every living thing (Isaiah 2:4, 60:18, and 65:25). This would include all humanity.

\section{Death of Many People}

Prophecies about the Second Coming of Jesus Christ foretold it causing the death of many people (Revelation 11:13), particularly wicked people (Malachi 4:1; Matthew 13:29; Isaiah 13:9). At least 
one- to two-thirds of men will be slain (Revelation 9:18). Men will also die of heart failure as a result of fear during the last days (Luke (21:26).

\section{Parallels Between Prophetic Visions and Prophecies from The Doctrine and Covenants in the Last Days}

Just as the events in NDE prophetic visions appear to parallel the cataclysmic events foretold by ancient prophets and Apostles of the Bible to occur on the Earth prior to the Second Coming of Jesus Christ, Mormon modern scripture seems to parallel both the PV and Bible prophecy in foretelling these events too. The Latter-day Saint (LDS) scripture used in this comparison is The Doctrine and Covenants, a volume of latter-day scripture that contains primarily selections from the direct revelations given to Joseph Smith from the Lord Jesus Christ over 150 years ago. Smith was the first president of the Church of Jesus Christ of Latter-day Saints, from 1830 to 1844.

\section{Geophysical Changes}

The Doctrine and Covenants referred to "earthquakes also in diverse places" (45:33) and a great earthquake at the Second Coming of Jesus Christ (45:48). This Mormon scripture also predicted "fire, and vapors of smoke" (45:41) that could be the result of volcanic eruptions. It also foretold of "the earth to tremble and to reel to and fro as a drunken man, and for valleys to be exalted, and for the mountains to be made low, and for the rough places to become smooth" $(49: 23 ; 45: 48 ; 88: 87,89)$ before the Second Coming. The sun will not give light and the moon will be bathed in blood during this time, too $(88: 87 ; 45: 42 ; 34: 9 ; 29: 14)$, and eventually the Earth's land masses will be one land (133:23).

\section{Meteorological Changes}

According to The Doctrine and Covenants, the weather of the future Earth will experience thunder, lightning, violent winds and storms, 
and the waves of the seas heaving beyond their bounds (88:90), and there will be changes in the times and seasons (121:12).

\section{Supply and Economic Breakdowns}

The Doctrine and Covenants predicted that everything will be in commotion on the future Earth (88:91), suggesting not only commotion in nature but also in economic systems. It foretold of a time when no person will be safe upon the waters $(61: 15 ; 42: 35)$. Hailstorms will also destroy the crops of the Earth (29:16, 109:30). Supply and economic breakdowns and the collapse of the world economic system are also implied by famines and wars, but not specifically mentioned.

\section{Nuclear War}

The Doctrine and Covenants foretold of wars and rumors of wars (45:26) just as did Matthew. Wars shall be upon the Earth and the wicked will slay the wicked and every person will experience fear because of these wars (63:33). There is no specific reference to the most vicious war in history, as in Bible prophecy, but that does not exclude such a war or the use of nuclear weapons in the prophesied future wars.

\section{Era of Universal Love and World Peace}

The Doctrine and Covenants also described a period of time following the Second Coming of Jesus Christ that will be a period where enmity will cease among all flesh and there will be no sorrow $(101: 26,29)$.

\section{Death of Many People}

The wicked will perish at the Second Coming according to Doctrine and Covenants prophecies (133:51), just as in Bible prophecies, and men will also die of heart failure as a result of fear during the last days (45:26). 


\section{Time Frame for Elements to Occur in Bible and Doctrine and Covenants Prophecies}

I noted above that most NDErs in Ring's study felt the major PV events would occur during the 1980 s, and that most of them agreed there were no fixed dates for specific events to occur. Most of Ring's subjects were convinced of the general direction of these events and that the PV scenario was inevitable.

The prophecies in the Bible and The Doctrine and Covenants seem to center around one major event: the Second Coming of Christ. They predicted the elements of the PV to occur before the Second Coming, but no date was specified. The Doctrine and Covenants $(77: 6,12)$ stated that Jesus Christ will come "in the beginning of the seventh thousand years," in reference to Biblical chronology. Although it is unknown how many years elapsed between Adam and the birth of Christ, the Irish Archbishop James Usher spent a great deal of his life attempting to establish just such a time period (Skousen, 1971), and found it to be 4,004 years. Further, it is uncertain from historical sources how many years have passed since the birth of Christ, but it is probably around 2,000 years. If this is the case, then the beginning of the seventh thousand years is in the beginning of the $21^{\text {st }}$ century and should begin around the year A.D. 2000. This would be consistent with the statement made in Ring's (1984) composite PV model: "The future scenario, however, is usually of short duration, seldom extending much beyond the beginning of the twenty-first century" (p. 197). Of course, these calculations depend on the accuracy of Biblical chronology and our calendar system.

\section{A Comparison of NDE Prophetic Vision Elements and Features to Bible Prophecies and Doctrine and Covenants Prophecies}

Just how closely NDE prophetic vision elements and other features correspond to Bible prophecies and prophecies in The Doctrine and Covenants is a fascinating question. Table 1 can assist in an examination of this question. There is a strong congruence between the elements and features of the NDE prophetic vision and their appearance in the prophecies for a period of time known as the last days in both the Bible and The Doctrine and Covenants. The NDE PVs 


\section{Table 1}

The Appearance of NDE Prophetic Vision Elements and Features in Bible Prophecies and Doctrine and Covenants Prophecies

\begin{tabular}{lll}
\hline \multicolumn{1}{c}{$\begin{array}{l}\text { NDE Prophetic } \\
\text { Vision Element }\end{array}$} & \multicolumn{1}{c}{$\begin{array}{c}\text { Bible } \\
\text { Prophecy }\end{array}$} & \multicolumn{1}{c}{$\begin{array}{c}\text { Doctrine and } \\
\text { Covenants } \\
\text { Prophecy }\end{array}$} \\
\hline earthquakes & yes & yes \\
volcanic activity & implied & implied \\
landmass changes & yes & yes \\
meteorological changes & yes & yes \\
supply and economic breakdowns & implied & implied \\
nuclear war & yes & no, but likely \\
death of many people & yes & yes \\
era of universal love and world peace & yes & yes \\
events to occur in 1980s & prior to & prior to \\
& Second Coming & Second Coming \\
\hline
\end{tabular}

and the prophecies in the Bible and The Doctrine and Covenants tend to corroborate one another.

There are no contradictions in these prophecies, although in the PV model the elements of volcanic activity and the collapse of the economic system are specifically identified. These elements are indirectly implied in the prophecies of both the Bible and The Doctrine and Covenants; the latter did state that all things will be in commotion.

Where the PV model indicates the possibility of nuclear war, prophecies in the Bible and The Doctrine and Covenants specifically stated wars will be occurring, but not the type of weaponry that will be used in them. There is always the possibility in this age that warring factions will use nuclear weapons. Bible prophecy did mention a war will occur that will be the most vicious war in history, which would suggest that such a war will involve nuclear weaponry.

While the PV model states that many people will die during these calamities, Bible and Doctrine and Covenants prophecies are more 
specific about who will die: they both stated it will be wicked people primarily who will die.

The dates for the events of the PV are not fixed; however, according to the PV model constructed by Ring most of the NDErs felt the events would occur during the 1980s. The Bible and Doctrine and Covenants prophecies were not specific about fixed dates either. However, the events were prophesied to occur prior to the Second Coming of Christ. The Doctrine and Covenants specified that that event will happen in the beginning of the $21^{\text {st }}$ century, which is consistent with the PV model's future scenario that does not extend much beyond the beggining of the $21^{\text {st }}$ century.

\section{Conclusion}

This examination of the parallels between elements and features in NDE prophetic visions and their appearance in prophecies for the Earth's future from the Bible and modern Mormon holy writ shows that the elements and features of the PV are also found in these other prophecies. These events have not only been seen and foretold by NDErs who have had prophetic visions, but also by ancient prophets and visionaries, as well as by Jesus Christ Himself. Over the centuries prophets, seers, visionaries, and futurists have seen the close of this millennium as the end of time as we know it. NDE prophetic visions, Bible prophecies, and prophecies from The Doctrine and Covenants lend support to this view.

If these prophecies are accurate, then the world can expect to witness more and ever worse catastrophic events that will culminate in a much different world than the one we now know. It is prophesied that it will be a world of universal love and peace, and that it may occur very soon. As one NDEr in Ring's (1984) study stated: "I had a feeling that there isn't much time left . . . There's an urgency about it [getting people to get along and care about each other and other life on this planet] because there isn't that much time" (p. 206). However, until the new world arrives it will become a very deadly world, particularly for those who are wicked in the Christian sense of the term.

The consistency found in these prophecies and their predictions certainly give ample reason for their careful consideration by neardeath researchers and the world. Plausible cause for such scrutiny is the fact that the future events in flashforwards and PVs reported 
in the literature have not occurred so far. There has been some difficulty in dating events in PVs, but as Grey (1985) has written, "there is no such thing as time (as we understand it) on the 'other side,' and it is well known that predictions are notoriously difficult to date correctly" (p. 181). However, it should also be kept in mind that the NDErs who had PVs did agree there were no fixed dates for specific events to occur.

This study suggests that to ignore these prophecies or to brush them aside as meaningless will be at our own risk and may be the most serious and deadly mistake we could ever make. It could mean the difference between life and death.

\section{References}

Brinkley, D., and Perry, P. (1994). Saved by the light. New York, NY: Villard.

The doctrine and covenants of the Church of Jesus Christ of Latter-day Saints. (1979).

Salt Lake City, UT. The Church of Jesus Christ of Latter-day Saints.

Gallup, G., and Proctor, W. (1982). Adventures in immortality: A look beyond the threshold of death. New York, NY: McGraw-Hill.

Grey, M. (1985). Return from death: An exploration of the near-death experience. London, England: Arkana.

The Holy Bible: Authorized King James Version. (1979). Salt Lake City, UT: The Church of Jesus Christ of Latter-day Saints.

Lundahl, C. R. (1983). Otherworld personal future revelations in near-death experiences. Journal of Near-Death Studies, 3, 171-179.

Ring, K (1980). Life at death: A scientific investigation of the near-death experience. New York, NY: Coward, McCann and Geoghegan.

Rink, K. (1982). Precognitive and prophetic visions in near-death experiences. Anabiosis: The Journal of Near-Death Studies, 2, 47-74.

Ring, K. (1984). Heading toward omega: In search of the meaning of the near-death experience. New York, NY: Morrow.

Ritchie, G. R. (1991). My life after dying: Becoming alive to universal love. Norfolk, VA: Hampton Roads.

Skousen, W. C. (1971). The first 2,000 years. Salt Lake City, Utah: Bookcraft. 